\title{
The Adaptation of Student Communication Satisfaction Scale into Turkish Culture
}

\author{
Ömer BOZTEPE ${ }^{1}$
}

\begin{tabular}{l} 
ARTICLE INFO \\
\hline Article History: \\
Received 09.08 .2016 \\
Received in revised \\
form 05.10 .2016 \\
Accepted \\
Available online 01.01 .2017
\end{tabular}

Available online 01.01.2017

\begin{abstract}
The aim of this study was to analyze the reliability and validity of the Turkish version of Student Communication Satisfaction Scale (SCSS) (Goodboy, Martin \& Bolkan, 2009). Participants were 272 students of education faculty at Sakarya University. Confirmatory factor analysis of the 24 items, one factor and the uni-dimensional scale was found $\left(x^{2}=1318.35, \mathrm{df}=249\right.$, RMSEA $=.126, \mathrm{NFI}=.90$, $\mathrm{NNFI}=.91, \mathrm{CFI}=.92$, IFI=.92, SRMR=.087). The Turkish version of the scale was translated and checked by 5 English experts for language validation. The final Turkish version of the scale was formed. The reliability of the scale was found .91 . Overall findings demonstrated that this scale is a valid and reliable instrument for measuring students' tendency to communication satisfaction in Turkish culture.
\end{abstract}

(C) 2017IJERE. All rights reserved

Keywords:

Student Satisfaction, validity, reliability, confirmatory factor analysis

\section{INTRODUCTION}

Communication is defined as sharing thoughts, feelings and interaction between all the people. A fundamental characteristic of student-teacher relationships is relational development of student in the classroom (Frymier \& Houser, 2000; Goodboy, Martin \& Bolkan, 2009). A critical component of teaching is effective communication skills. If there is a

mismatch between what was intended to be conveyed and what is conveyed, then ineffective teaching outcomes even the best teaching decisions can be brought out (Low, Chong \& Ellis, 2014). One of the most important skills is having the ability to communicate properly within the workplace in order to ensure your ideas, wants, and needs are heard (Howard, 2014). Communication skills are described as a component of a complex set of skills which define clinical competence. There is a need to develop standardized assessments of these skills in order to evaluate student progress in communication skills. Teacher confirmation is the process through which instructors communicate to pupils so that they are recognized and acknowledged as significant individuals and valuable (Ellis, 2000; Goodboy \& Myers, 2008). Disconfirmation relates to a variety of behaviors that negatively affect self-experience and feelings of worth in three basic ways: imperviousness, disqualification and indifference, (Cissna \& Sieburg, 1981; Goodboy \& Myers, 2008). McNally (2005) states the teacher-student relationships as an integral part of the education process, especially student learning. Interpersonal and instructional communication researchers have increased their attention to the teacher-student relationship lately. Research at all levels of education has focused on the role of teacher as the one responsible for whether or not student learning occurs. Student perceptions of their instructors are affected by instructor's communication style in the college classroom. Communication satisfaction can be described as an effective response to the accomplishment of communication aims and

${ }^{1}$ Corresponding e-mail:omerboztepe87@gmail.com Sakarya University 1 
expectations (Hecht, 1978a; Goodboy, Martin \& Bolkan, 2009). The time when positive expectations are fulfilled and largely contextual, these result in communication satisfaction (Hecht, 1978b; Goodboy, Martin \& Bolkan, 2009). Although an output of communication competence considers communication satisfaction , interpersonal communication competence is constantly considered a part of conversational appropriateness and effectiveness (Egland \& Spitzberg, 1996; Spitzberg \& Cupach, 1984; Goodboy, Martin \& Bolkan, 2009). Both communication satisfaction and conversational appropriateness depend on the fulfillment of expectations and are theoretically identical construct; they should be correlated in a positive way. Recently student satisfaction concept and loyalty have attracted much attention and this is one of the main aims of all educational institutions. A user's post-purchase evaluation of a product or service defines satisfaction (Temizer \& Turkyilmaz, 2012). Higher student satisfaction will lead to a stronger competitive situation and result in attracting new pupils and maintaining the existing ones which is a key motivation for the growing emphasis on student satisfaction (Temizer \& Turkyilmaz, 2012). Education programs and in-service teacher training workshops are left by many teachers which get only half of the story. How our behaviors influence students and their learning can be learned. Much of the education and communication research on teaching and learning are examined as a linear, one-directional relationship by most of the communication and education research (Mottet \& Richmond, 2001). Using several communicative behaviors which are essential in any functional interpersonal relationship develop quality college instructor-student relationships. These include self-disclosure (Cayanus \& Martin, 2008; Goodboy, Myers \& Bolkan, 2010), affinity seeking (Myers, Martin, \& Knapp, 2005; Goodboy, Myers \& Bolkan, 2010), and confirmation (Goodboy \& Myers, 2008; Goodboy, Myers \& Bolkan, 2010). Because of college students' interest in developing interpersonal relationship with their instructor (Waldeck, 2007; Goodboy, Myers \& Bolkan, 2010), college instructors are obliged to engage in positive, confirming and prosocial forms of communication with their pupils. (Goodboy, Myers \& Bolkan, 2010). How people communicate to satisfy interpersonal needs and why people communicate with others explained by personal characteristics. (Graham, Barbato \& Perse, 1993 ; Martin, Myers \& Mottet, 1999). The main purpose of the study was to adapt and validate the Student Communication Satisfaction Scale (SCSS) into Turkish culture (Goodboy, Martin \& Bolkan, 2009). By the help of the scale, educators may learn their students' feelings towards them because communication is one of the vital factors in education life. This scale will help Turkish educators to develop their courses with the help of well communication with their pupils. They may get both positive and negative feedbacks about their communication with them. Another purpose of the study was to adapt a Turkish scale about student communication for next researches because it is really hard to find Turkish versions of such kind of instruments which is about communication in Turkish literature. This study will help much to the researchers who want to do an academically research about communication. 


\section{METHOD}

\section{Participants}

The sample of this research consisted of 272 education faculty students from Sakarya University, Turkey. The participant students study at different grades range from $1^{\text {st }}$ to $4^{\text {rd }}$ and 9 different departments of study. 188 female and 84 male participants were involved in the study. Their ages ranged between 17-34 years.

\section{Instrument}

The instrument of the study is Student Communication Satisfaction Scale (SCSS) which was developed by Goodboy, Martin \& Bolkan (2009). The instrument is a 24-item scale which is one factor and unidimensional. The reliability of the original scale was found Croncbach's alpha .97. It was a reliable measurement to use for a research. According to the results of the Confirmatory Factor Analysis of the original scale, the one-factor model was fitted to the data with the ML method of LISREL 8.8. (x2 (19)_36.71, pB.01; NC_1.93; CFI_.99; SRMR_.04; RMSEA_.08.) All loadings were significant (Goodboy, Martin \& Bolkan, 2009). After the research about the findings of the scale, it was decided to use this scale as a measurement instrument of this study.

\section{Procedure}

Before the research, an e-mail was sent to Goodboy and asked permission about using the scale. First, the scale was translated into Turkish by 5 expert English Teachers and the translated form was examined by them. Then, Turkish form of the scale was examined about grammatical rules and Turkish template was built up. Before starting the validity and the reliability of the scale, the construct validity was examined as a validity study. Confirmatory Factor Analysis was done for the construct validity. The reliability of the SCSS was analyzed with the internal consistency and the item analysis was done with total item correlation method. SPSS 22.0 and LISREL 8.71 package programs were used to analyze the validity and reliability of the scale.

\section{RESULTS}

Item-Total Correlations for the Turkish Version of Student Communication Satisfaction Scale are displayed Table 1.

Scale Item Factor Loading

1-Öğretmenimle iletişimim memnuniyet verici. .67

2-Öğretmenimle konuşunca kendimi hoşnut hissediyorum. .63

3-Öğretmenimle konuşunca genellikle olumlu şeyler hissediyorum. .65

4-Öğretmenim, sorularıma tatmin edici cevaplar vermek için çaba sarf ediyor.

5-Öğretmenimle iletişim kurduğumda kendimi bir parça da olsa mutlu hissediyorum.

.66 
6-Öğretmenimle konuşunca rahatllyorum. $\quad .58$

7-Öğretmenimle konuşmaktan hoşlanmıyorum.

8-Öğretmenimle konuştuktan sonra memnun olmuyorum.

9-Öğretmenimle konuştuğumda benim beklentilerimi karşıllıor.

10-Öğretmenimle konuşmalarımı zaman kaybı olarak görüyorum. $\quad .35$

11-Öğretmenimle yaptığım konuşmalar faydalıdır.

12-Öğretmenimle konuşmak memnuniyet vericidir. $\quad .65$

13-Öğretmenimle yaptığım konuşmalar benim için ümit vericidir. $\quad$ 64

14-Öğretmenim benim endişelerimi gidermek için çaba harcıyor. 61

15-Öğretmenim, keşke benimle daha iyi iletişim kursa. $\quad .30$

16.Öğretmenimle konuştuğumda beni gerçekten dinliyor.

17-Öğretmenimle konuşmalarım, keşke daha faydalı olsa. $\quad .37$

18.Öğretmenimle konuşmak istediğimde öğretmenim bana zaman ayırıyor.

19- Öğretmenimle yaptığım konuşmalar benim için değerlidir.

20-Öğretmenim konuşmalarımızda en çok söz alan taraftır, benim fikirlerimi belirtmeme pek izin vermez. .43

21-Öğretmenim benim sorularımı cevaplamak için çaba sarf ediyor.

22-Öğretmenimle etkili iletişim kurabiliyorum.

23-Öğretmenimle konuştuğumda, aramda bir bağ kurabiliyorum.

24-Öğretmenimle konuşunca, bir şey başarmışçasına mutlu hissediyorum

Table 1: Item-Total Correlations for the Turkish Version of SCSS.

\section{Construct Validity}

Confirmatory Factor Analysis is fairly functional for the investigators in terms of handling apparent hypotheses about a scale like, the number of factors or extents underlying its items, connections between absolute items or absolute factors and the link between factors. To put it other way, with CFA investigators assess "measurement hypotheses" regarding scale's internal structure. Furr and Bacharach (2008) propounded that CFA provides investigators to measure the degree to which their assessment hypotheses are consistent with the factual data of the scale. Confirmatory factor analysis indicates the unidimensional model. $\left(x^{2}=1318.35, \mathrm{df}=249\right.$, RMSEA=.126, NFI=.90 NNFI=.91,CFI=.92,IFI=.92,SRMR=.087).

Factor loadings and path diagram for Turkish version of SCSS are displayed in Figure 1.1 


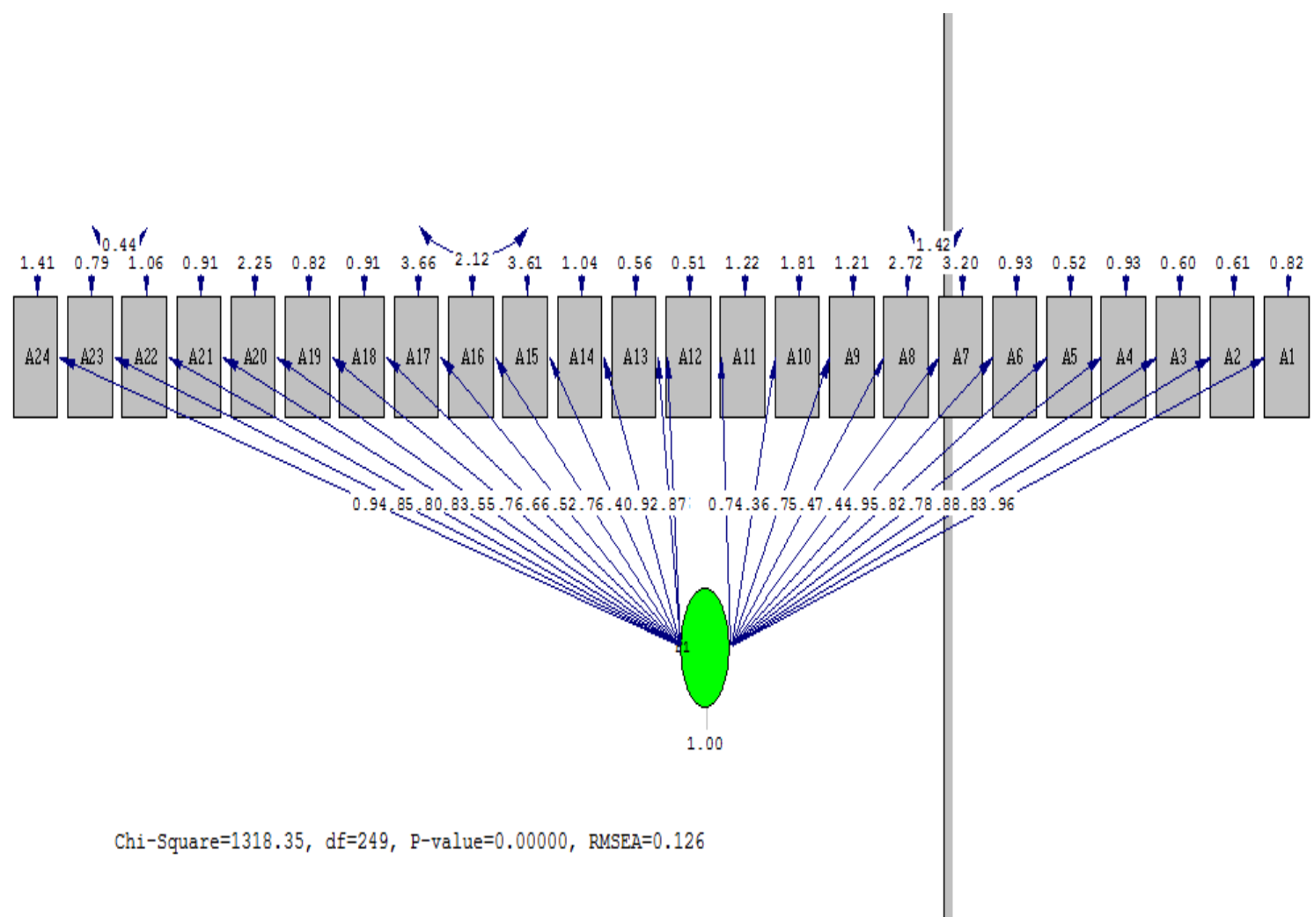

Figure 1.1: Factor Loadings and Path Diagram for the SCSS

\section{Reliability}

The Cronbach's Alpha internal consistency reliability coefficients of the scale were .91 for whole scale.

\section{Discussion}

The purpose of this study was to adapt the SCSS into Turkish and examine reliability and validity. Confirmatory factor analysis showed the harmony of factor structure of the original scale. The structural model of the SCSS which forms one factor was moderate suitable for the Turkish culture (Bentler \& Bonett, 1980; Hu \& Bentler, 1999; Schermelleh-Engel \& Moosbrugger, 2003). The internal consistency reliability coefficients of the scale were high (Kline, 2000; Büyüköztürk, 2010). It was considered that item total correlations having a value of .30 (Büyüköztürk, 2010). The 24 items loaded on one factor and the unidimensional model was acceptable which was demonstrated by the results of confirmatory factor analysis $\left(x^{2}=1318.35, \mathrm{df}=249\right.$, RMSEA $=.126, \mathrm{NFI}=.90, \mathrm{NNFI}=.91, \mathrm{CFI}=.92, \mathrm{IFI}=.92$, SRMR $=.087$ ). The internal consistency coefficients reliability of the scale was .91. The corrected item-total correlations of SCSS ranged from .37 to .67. There are some limitations of the present study. Its sample size is one of the limitations of the current study. Specifically, further studies should examine the same scale with a larger sample size. A larger sample size may clarify some correlations and so boost the validity of the findings. Furthermore, conducting this study in different universities of Turkey may show whether these results could be generalized to a wider population. Another limitation of the current study is that the sample was consists of pre-graduate 
students, which restricted the generalizability of the conclusions. Hereby, it could be important to inspect the relationship of these variables in other sample groups. Overall findings showed that this scale had high validity and reliability scores and that it may be used as a valid and reliable instrument in order to measure the individuals' satisfaction about communicating with their instructors. Nevertheless, future studies that will use SCSS are important for its measurement effectiveness.

\section{REFERENCES}

Büyüköztürk, Ş. (2010). Veri analizi el kitabı. Ankara: Pegem A Yayıncılık

Furr, R. M., \& Bacharach, V. R. (2013). Psychometrics: an introduction. Sage.

Goodboy, A. K., \& Myers, S. A. (2008). The effect of teacher confirmation on student communication and learning outcomes. Communication Education, 57(2), 153-179.

Goodboy, A. K., Martin, M. M., \& Bolkan, S. (2009). The development and validation of the student communication satisfaction scale. Communication Education, 58(3), 372-396.

Goodboy, A. K., Myers, S. A., \& Bolkan, S. (2010). Student motives for communicating with $\quad$ instructors as a function of perceived instructor misbehaviors. Communication Research Reports, 27(1).

Howard, Melissa.(2014). Effective Communication in Higher Education. Individual Applied Research Thesis: Effective Communication in Higher Education Due: September 21st, 2014

Low, E. L., Chong, S., \& Ellis, M. (2014). Teachers' English communication skills: Using IELTS to measure competence of graduates from a Singaporean teacher education program. Australian Journal of Teacher Education, 39(10), 5.

Martin, M. M., Myers, S. A., \& Mottet, T. P. (1999). Students' motives for communicating $\quad$ with $\quad$ their instructors. Communication Education, 48(2), 155 164.DOI:10.1080/03634529909379163

McNally, Jacqueline S.(2005) Teacher-Student Relationships: The Effects Of Student Motives, Relationship Development, And Communication On Student Learning. College of Communication and Information of Kent State University, Doctor of Philosophy, May,2005.

Mottet,Timothy P.\& Richmond, Virginia P.(2001).Communication and Its Influence on Teachers and Teaching.05/S1/Chesebro/47-62. Chapter5 Student Nonverbal Communication.

Schermelleh-Engel, K., Moosbrugger, H., \& Müller, H. (2003). Evaluating the fit of structural equation models: Tests of significance and descriptive goodness-of-fit measures. Methods of psychological research online, 8(2), 23-74.

Temizer, L., \& Turkyilmaz, A. (2012). Implementation of student satisfaction index model in higher education institutions. Procedia-Social and Behavioral Sciences, 46, 38023806.

\section{ÖĞRENCİ İLETIŞIMI MEMNUNIYET ÖLÇEĞİ}

\begin{tabular}{|c|c|c|c|c|c|c|c|c|}
\hline & $\begin{array}{l}\text { Her sorunun karşısında bulunan; (1), Kesinlikle Katılmıyorum (2) } \\
\text { Katılmıyorum (3) Kısmen katılmıyorum (4)Kararsızım (5)Kısmen katılıyorum } \\
\text { (6) Katılıyorum ve (7) Kesinlikle katılıyorum anlamına gelmektedir. Lütfen } \\
\text { her ifadeye mutlaka TEK yanıt veriniz ve kesinlikle boş bırakmayınız. }\end{array}$ & 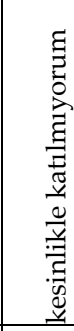 & $\begin{array}{l}\text { ह } \\
\text { E }\end{array}$ & 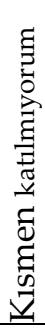 & 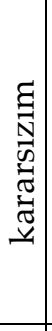 & 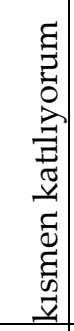 & 胥 & \\
\hline 1 & Öğretmenimle iletişimim memnuniyet vericidir. & 1 & 2 & 3 & 4 & 5 & 6 & \\
\hline
\end{tabular}




\begin{tabular}{|c|c|c|c|c|c|c|c|c|}
\hline 2 & Öğretmenimle konuşunca kendimi hoşnut hissediyorum. & 1 & 2 & 3 & 4 & 5 & 6 & 7 \\
\hline 3 & Öğretmenimle konuşunca genellikle olumlu şeyler hissediyorum. & 1 & 2 & 3 & 4 & 5 & 6 & 7 \\
\hline 4 & Öğretmenim, sorularıma tatmin edici cevaplar vermek için çaba sarf ediyor. & 1 & 2 & 3 & 4 & 5 & 6 & 7 \\
\hline 5 & $\begin{array}{l}\text { Öğretmenimle iletişim kurduğumda kendimi bir parça da olsa mutlu } \\
\text { hissediyorum. }\end{array}$ & 1 & 2 & 3 & 4 & 5 & 6 & 7 \\
\hline 6 & Öğretmenimle konuşunca rahatlıyorum. & 1 & 2 & 3 & 4 & 5 & 6 & 7 \\
\hline 7 & Öğretmenimle konuşmaktan hoşlanmıyorum. & 1 & 2 & 3 & 4 & 5 & 6 & 7 \\
\hline 8 & Öğretmenimle konuştuktan sonra memnun olmuyorum. & 1 & 2 & 3 & 4 & 5 & 6 & 7 \\
\hline 9 & Öğretmenimle konuştuğumda benim beklentilerimi karşılıyor. & 1 & 2 & 3 & 4 & 5 & 6 & 7 \\
\hline 10 & Öğretmenimle konuşmalarımı zaman kaybı olarak görüyorum. & 1 & 2 & 3 & 4 & 5 & 6 & 7 \\
\hline 11 & Öğretmenimle yaptığım konuşmalar faydalıdır. & 1 & 2 & 3 & 4 & 5 & 6 & 7 \\
\hline 12 & Öğretmenimle konuşmak memnuniyet vericidir. & 1 & 2 & 3 & 4 & 5 & 6 & 7 \\
\hline 13 & Öğretmenimle yaptığım konuşmalar benim için ümit vericidir. & 1 & 2 & 3 & 4 & 5 & 6 & 7 \\
\hline 14 & Öğretmenim benim endişelerimi gidermek için çaba harcıyor. & 1 & 2 & 3 & 4 & 5 & 6 & 7 \\
\hline 15 & Öğretmenim, keşke benimle daha iyi iletişim kursa. & 1 & 2 & 3 & 4 & 5 & 6 & 7 \\
\hline 16 & Öğretmenimle konuştuğumda beni gerçekten dinliyor. & 1 & 2 & 3 & 4 & 5 & 6 & 7 \\
\hline 17 & Öğretmenimle konuşmalarım, keşke daha faydalı olsa. & 1 & 2 & 3 & 4 & 5 & 6 & 7 \\
\hline 18 & Öğretmenimle konuşmak istediğimde öğretmenim bana zaman ayırıyor. & 1 & 2 & 3 & 4 & 5 & 6 & 7 \\
\hline 19 & Öğretmenimle yaptığım konuşmalar benim için değerlidir. & 1 & 2 & 3 & 4 & 5 & 6 & 7 \\
\hline 20 & $\begin{array}{l}\text { Öğretmenim konuşmalarımızda en çok söz alan taraftır, benim fikirlerimi } \\
\text { belirtmeme pek izin vermez. }\end{array}$ & 1 & 2 & 3 & 4 & 5 & 6 & 7 \\
\hline 21 & Öğretmenim benim sorularımı cevaplamak için çaba sarf ediyor. & 1 & 2 & 3 & 4 & 5 & 6 & 7 \\
\hline 22 & Öğretmenimle etkili iletişim kurabiliyorum. & 1 & 2 & 3 & 4 & 5 & 6 & 7 \\
\hline 23 & Öğretmenimle konuştuğumda, aramda bir bağ kurabiliyorum. & 1 & 2 & 3 & 4 & 5 & 6 & 7 \\
\hline 24 & Öğretmenimle konuşunca, bir şey başarmışçasına mutlu hissediyorum. & 1 & 2 & 3 & 4 & 5 & 6 & 7 \\
\hline
\end{tabular}

